\title{
Kepemimpinan Transformasional dan Efikasi Diri Terhadap Kinerja Karyawan
}

\author{
Muzakki $^{1)^{*}}$ Anggita Rinda Pratiwi ${ }^{1)}$ \\ Universitas Airlangga \\ Jalan Airlangga No. 4 - 6, Airlangga, Surabaya-Jawa Timur, Indonesia \\ *Email: muzakki0707@gmail.com
}

\begin{abstract}
Artikel Info ABSTRAK
Dikirim:

Tujuan penelitian ini adalah untuk mengetahui pengaruh secara parsial dan simultan

17Juli2019 transformational leadership dan self-efficacy terhadap job performance. Sampel pada

Revisi: penelitian ini adalah karyawan pada PT. Panca Mitra Multiperdana. Teknik pengambilan

19September 2019

Diterima: sampling yang digunakan dalam penelitian ini adalah random sampling dengan jumlah sampel yang diambil sebanyak 128. Sedangkan, untuk pengumpulan data kami menggunakan 27 September2019 kuesioner yang telah di uji validitas dan reliabilitasnya. Teknik analisis data yang digunakan dalam penelitian ini adalah analisis regresi linier berganda. Disisi lain, Temuan penelitian ini mengungkapkan bahwa secara parsial konstruk transformational leadership dan self-efficacy memiliki pengaruh positif dan signifikan terhadap job performance. Selain itu, secara simultan kedua konstuk job performance tersebut juga memiliki pengaruh secara positif dan signifikan.
\end{abstract}

Kata Kunci :Transformational leadership,self-efficacy, job performance.

\section{Transformational Leadership and Self-Efficacy on Job Performance}

\begin{abstract}
The purpose of this study was to study partial and simultaneous research of transformational leadership and self-efficacy on job performance. The sample in this study were employees at PT. Panca Mitra Multiperdana. The sampling technique used was random sampling with the number of samples taken were 128 employees. Meanwhile, to collect our data using a questionnaire that has been tested for validity and reliability. The data analysis technique used is multiple linear regression analysis. The findings of this study reveal that transformational leadership and self-efficacy have a positive and significant influence on employee job performance partially. Besides, simultaneously both constructs of job performance also have a positive and significant effect.
\end{abstract}

Keyword :Transformational leadership,self-efficacy, job performance

Cara Sitasi :

Muzakki., \& Pratiwi, A. R. (2019). Kepemimpinan Transformasional dan Efikasi Diri Terhadap Kinerja Karyawan. Jurnal Ilmiah Manajemen dan Bisnis, 20(2), 82-91. https://doi.org/10.30596/jimb.v20i2.3264. 


\section{Jurnal Ilmiah Manajemen dan Bisnis}

ISSN 1693-7619 (Print) I ISSN 2580-4170 (Online)

\section{PENDAHULUAN}

Era kontemporer persaingan bisnis menjadi semakin ketat, hal ini didukung dengan adanya perkembangan teknologi ekonomi, pendidikan dan sosial budaya. Sehingga, mempengaruhi pentingnya penerapan strategi yang tepat agar sebuah perusahaan tetap dapat bertahan dan bersaing dengan kompetitornya. Untuk dapat bersaing dengan sukses, terdapat satu hal yang tidak bisa dilupakan oleh perusahaan yaitu pemangku kepentingan utama dalam organisasi/perusahaan itu sendiri, dalam hal ini adalah karyawan. Dimana, karyawan telah diyakini sebagai tombak utama keberhasilan organisasi/perusahaan, secara literatur karyawan telah dianggap sebagai aset penting suatu organisasi (Gabcanova, 2011). Bahkan, Seorang manajer dapat dengan mudahnya melakukan pekerjaan dan meningkatkan kinerja mereka, salah satu sebabnya adalah karena ditunjang dengan meningkatkan kinerja karyawan. Disisi lain, karyawan memiliki peranan yang cukup penting dalam semua pekerjaan baik pekerjaan yang berada pada level white - collar wokers maupun pada level blue - collar wokers. Menjadi sangat penting untuk diperhatikan oleh para manajer yaitu terkait dengan kinerja seorang karyawan dalam organisasi/perusahaan mereka.

Kinerja merupakan tolok ukur keberhasilan kerja baik kualitas maupun kuantitas dalam jangka waktu tertentu dipengaruhi oleh banyak faktor dan dilakukan oleh karyawan sesuai dengan tanggung jawab yang diberikan kepadanya untuk mencapai tujuan organisasi (Bernardin \& Russel, 1993). Kinerja ini penting untuk terus dijaga baik oleh karyawan maupun organisasi sebagai landasan untuk mencapai tujuan organisasi secara keseluruhan. Disisi lain, Tingginya kinerja karyawan dapat berimplikasi pada peningkatan kinerja organisasi. Sehingga, kinerja karyawan ini dianggap sebagai tolak ukur suatu organisasi/perusahaan sukses atau tidak.
PT Panca Mitra Multiperdana Tbk. ("Perseroan") merupakan salah satu produsen hasil olahan udang dengan kapasitas produksi dan kapasitas penyimpanan cold storage terbesar di Indonesia. Perusahaan ini menjalankan bisnis dengan membeli udang mentah segar dan berkualitas dari petambak, lalu memprosesnya menjadi beragam produk olahan (seperti; skewered, nobashi ebi, sushi ebi, breaded shrimp, headless dan produkproduk lainnya). Kemudian, mayoritas produk olahan udang yang telah diproduksi diekspor ke luar negeri, dengan lebih dari 95\% pengiriman ditujukan terhadap beberapa negara maju, salah satunya Amerika Serikat dan Jepang. Pelanggan perusahaan ini juga didominasi oleh peritel besar di negara asalnya seperti; Walmart, Blue Sea, Certifresh, dan CP Food di AS; serta Maruha Nichiro dan Marubeni di Jepang.

Namun, terdapat masalah yang terjadi yaitu berkaitan dengan penjualan produk mulai dari tahun 2015 sampai tahun 2017 yang perusahaan edarkan pada beberapa negara (Amerika, Jepang, dan Negara lainnya). Data penurunan penjualan tersebut dapat ditampilkan dalam Gambar 1.

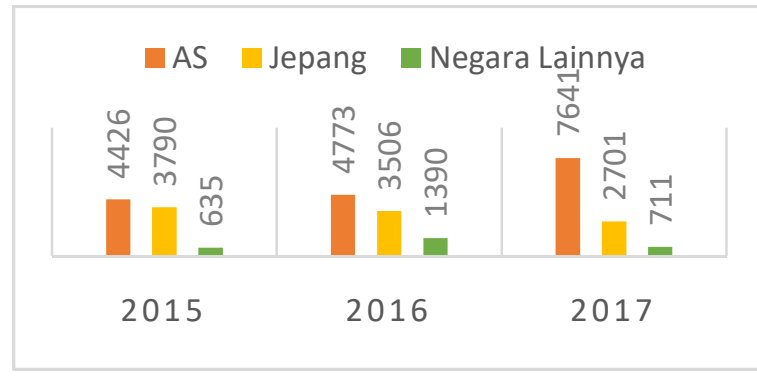

Gambar 1. Penjualan (Ton) Tahun 2015 sampai 2017

Melihat dari data penjualan perusahaan pada tahun 2015 sampai 2017 dapat dilaporkan bahwa, penjualan terhadap negara Amerika Serikan meningkat. Sedangkan, penjualan pada negara Jepang terjadi penurunan secara beruntun dari tahun 2015 sampai 2017, secara berurutan penjualan tersebut adalah 3790ton, 3506 ton, dan 2701 ton. Selain itu, untuk penjualan pada Negara lain lebih cenderung fluktuatif atau cenderung 


\section{Jurnal Ilmiah Manajemen dan Bisnis}

naik turun, hal ini dibuktikan melalui data penjualan yang diperoleh secara berurutan dari tahun 2015 sampai 2017 adalah 635ton, 1390 ton, dan 711 ton. Hal ini mencerminkan bahwa kinerja organisasi yang kurang baik, dan ada kemungkinan diinisiasi oleh kinerja karyawan, sehingga terjadi penurunan angka penjualan dari tahun 2015 sampai 2017 walaupun pada penjualan negara Amerika Serikat terjadi peningkatan. Penurunan kinerja perusahaan ini menurut Koesmono (2005) dipengaruhi oleh penurun kinerja karyawan. Apabila ini terus berlanjut maka organisasi akan memiliki masalah yang cukup besar dalam perkembangan bisnis mereka di masa mendatang. Sehingga, permasalahan tersebut tidak boleh dibiarkan bahkan harus bisa diberikan solusi strategis dan ditangani sedini mungkin. Menurut beberapa ahli masalah kinerja karyawan ini dapat diselesaikan melalui penerapan kepemimpinan yang baik, salah satunya adalah kepemimpinan transformasional (Buil et al., 2019; Braun et al., 2013; Givenss, 2008; Piccolo \&Colquitt, 2006)

Kepemimpinan dianggap sebagai aktivitas untuk mempengaruhi orang lain agar dapat mencapai tujuan organisasi (Thoha, 2006). Hal ini biasanya ditunjukkan melalui pemimpin yang dapat membawa suatu perubahan yang positif, energik, antusias dan bergairah. Disisi lain, pemimpin memiliki peran yang sangat penting untuk meningkatkan kinerja karyawan. Seperti yang dijelaskan oleh Balthazard et al. (2009)dan Lievens et al. (1997) bahwasanya efektivitas pemimpin melalui kepemimpinan transformasional memiliki pengaruh yang signifikan dalam pengambilan keputusan team yang pada akhirnya dapat meningkatkan kinerja karyawan. Disisi lain, Eliyana et al. (2019)mengungkapkan bahwa dampak yang didapatkan apabila sebuah organisasi dapat menerapkan kepemimpinan transformasional adalah secara langsung dapat memberikan implikasi pada komitmen organisasional dan kepuasan kerja, serta dampaknya pada kinerja yang dirasakan oleh karyawan. Tidak hanya itu saja, tapi kepemimpinan transformasional menurut Performance Management Counseling (2011) juga memfokuskan bagaimana caranya dapat membantu setiap anggota kelompok (team) dapat berhasil.

Selain itu, dalam beberapa tahun ini juga kepemimpinan transformasional dianggap sebagai kepemimpinan yang paling efektif dan sesuai dengan karyawan (Birasnav, 2014). Menurut Burns yang dikutip oleh Brandt, et al.(2016) menyatakan bahwa kepemimpinan transformasional merupakan suatu transformasi dimana atasan dalam hal ini pemimpin dan bawahan terlibat dalam proses saling memacu satu sama lain, dengan tujuan untuk mencapai tingkat yang lebih tinggi dalam moralitas dan motivasi. Bass (2003) melaporkan bahwa pemimpin transformasional lebih condong untuk menunjukkan atribut karisma yang saling menguatkan, motivasi inspirasional, stimulus intelektual, dan pertimbangan individu. Disisi lain, Brandt et al., (2016) mengungkapkan bahwa pemimpin transformasional memiliki inisiatif untuk menyalurkan kepentingan pribadi pengikut mereka untuk kebaikan kelompok dan organisasi. Selain itu, pemimpin transformasional mampu memotivasi karyawan dengan mendapatkan rasa hormat dan kepercayaan mereka, pada saat yang sama juga dapat mendukung/ mendorong karyawannya untuk bekerja dengan cara yang efisien untuk mencapai tujuan dari pemimpin mereka (Robbins et al., 2009).

Selanjutnya, tidak hanya cukup dengan pemimpin yang dapat memberikan pengaruh pada kinerja karyawan, namun pada sisi karyawan sendiri harus ada dorongan dan keyakinan tentang kemampuan mereka dalam menyelesaikan tugasnya, hal ini biasanya disebut sebagai self-efficacy. Self-efficacy ini merupakan penilaian karyawan terhadap kemampuan atau kompetensinya dalam menyelesaikan tugas, mencapai tujuan, dan menghasilkan sesuatu (Baron \& Byrne, 2004). 


\section{Jurnal Ilmiah Manajemen dan Bisnis}

ISSN 1693-7619 (Print) I ISSN 2580-4170 (Online)

Self-efficacy ini oleh Pervin \& John, (2001) diyakini sebagai salah satu potensi yang ada pada faktor kognitif manusia, dimana itu merupakan bagian dari penentu tindakan manusia selain lingkungan dan dorongan internal. Disisi lain, self-efficacy ini merupakan aspek yang paling penting dari persepsi yang merupakan bagian fungsi kognitif (Pervin \& John, 2001). Seseorang yang memiliki self efficacy yang tinggi dapat mencurahkan semua usaha dan perhatiannya untuk mencapai tujuan yang telah ditentukan, sedangkan individu yang memiliki selfefficacy yang rendah cenderung malas untuk berusaha ketika menghadapi situasi yang sulit. Menurut Bandura (1997)self-efficacy dapat ditumbuhkan dan dipelajari malalui 4 sumber yaitu kinerja masa lalu, model perilaku mengamati orang lain yang melakukan tindakan yang sama, persuasi dari orang lain dan keadaan fisiologis dan emosional. Dampak positif yang dapat dibentuk dari selfefficacy adalah kinerja karyawan (Lunenburg, 2011; Carter et al., 2016; Clercq et al., 2018).

Pada beberapa penelitian yang serupajuga disebukan bahwa self-efficacy ini merupakan faktor penting dalam meningkatkan job performance karyawan Lunenburg, 2011; Carter et al., 2016; Clercq et al., 2018). Self-efficacy beberapa tahun ini telah dikenal sebagai teori kognitif sosial atau teori pembelajaran sosial, dimana diyakini sebagai keyakinan seseorang bahwa mereka mampu melakukan tugas tertentu dengan sukses (Bandura, 1997). Hal ini selaras dengan penjabaran atas teori COR seperti yang disebutkan oleh Clercq et al. (2018) bahwa self-efficacy mencerminkan sumber daya pribadi yang kritis yang merangsang keterlibatan karyawan dalam kegiatan peningkatan kinerja. Beberapa hal tersebut telah memberikan bukti bahwa pentingnya self-eficacy terkait dengan keyakinan karyawan dalam menyelesaikan tugasnya harus dimiliki oleh setiap pribadi karyawan.Selain juga organisasi memberikan dukungan terhadap mereka melalui kepemimpinan transformasional dalam peningkatan kinerjanya.

Faktor-faktor yang menjadi antesiden kinerja tersebut telah dikaji secara mendalam oleh banyak penelitian, sehingga penelitian ini juga menjadi penting untuk dilakukan. Dengan pertimbangan bahwa hasil penelitian ini akan memberikan sumbangsih terhadap penelitian yang serupa terkait dengan Human Resource Management, selain itu juga akan menjadi pertimbangan khusus bagi praktisi selaku penggerak dunia bisnis dan usaha, dimana hasil penelitian ini dapat menjadi pertimbangan kebijakan dalam pengambilan keputusan mereka dalam praktek bisnisnya. Dalam penelitian ini job performance karyawan diukur melalui dua konstruk yaitu transformational leadership $\left(\mathrm{X}_{1}\right)$ dan selfeficacy $\left(\mathrm{X}_{2}\right)$. Dimana dari kedua konstruksi ini akan diteliti apakah memiliki pengaruh terhadap job performance (Y).

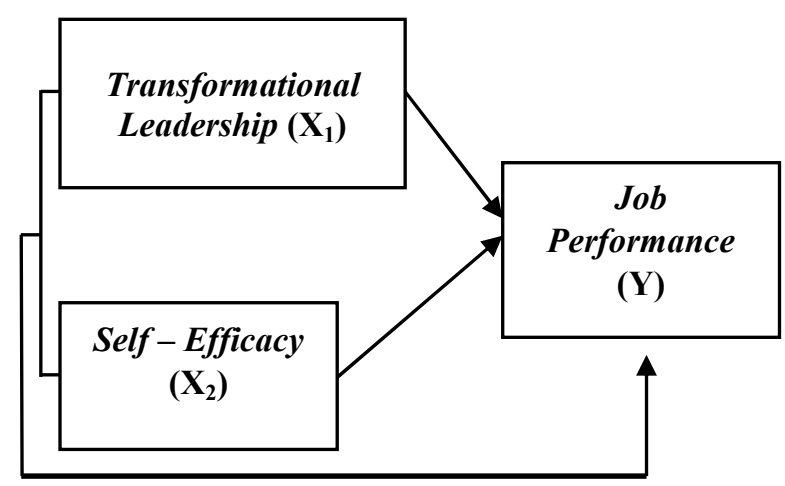

Gambar 2.Kerangka Konseptual

\section{METODE}

Pada penelitian ini, jenis penelitian yang digunakan adalah penelitian kuantitatif, dimana penelitian ini menggunakan angkaangka statistik dalam melakukan analisis. Populasi dalam penelitian ini merupakan karyawan pada PT. Panca Mitra Multiperdana, dengan sampel yang digunakan sebanyak 128 responden. Sedangkan, pengumpulan data menggunakan instrument penelitian yaitu melalui kuesioner yang disebarkan pada 


\section{Jurnal Ilmiah Manajemen dan Bisnis}

ISSN 1693-7619 (Print) I ISSN 2580-4170 (Online)

karyawan, yang kemudian diolah dan dianalisis menggunakan SPSS 21.

Variabel dalam penelitian ini diukur dengan mengadopsi dari beberapa ahli, yaitu untuk variabel transformational leadership diadopsi dari pengukuran yang ditawarkan oleh Bass et al., (2003) melalui 12 items berdasarkan skala multifactors leadership. Self-efficacy mengadopsi dari pengukuran yang dicetuskan oleh Luthans et al. (2007)dan Parker (1998) menggunakan 6 item. Sedangkan, untuk kinerja karyawan (job performance) kami mangadopsi dari Abbas et al. (2014)dan Williams \& Anderson (1991) menggunakan tujuh item. Semua item dari ketiga variabel tersebut dinilai berdasarkan 4 skala liker berdasarkan rating yaitu 1 (sangat tidak setuju) sampai 4 (sangat setuju). Sedangkan, Analisis yang digunakan dalam penelitian ini menggunakan analisis regresi linier berganda, dimana pada penelitian ini data yang dianalisis berasal dari dua variabel sebagai variabel independen (X) dan satu variabel terikat (Y). Bentuk persamaan berganda terhadap dua variabel independen (X) adalah sebagai berikut: $\mathrm{Y}=\mathrm{a}+\beta 1 \mathrm{X} 1+$ B2 X2 + e

Dimana:

$$
\begin{array}{ll}
\mathrm{Y} & =\text { Job performance } \\
\mathrm{X} 1 & =\text { Transformational leadership } \\
\mathrm{X} 2 & =\text { Self-efficacy } \\
\mathrm{e} & =\text { error } \\
\mathrm{a} & =\text { Konstanta } \\
\beta 1, \beta 2 & =\text { Koefisien regresi }
\end{array}
$$

\section{HASIL DAN PEMBAHASAN}

Uji validitas yang dilakukan dalam penelitian ini menggunakan teknik Product Moment Pearson Correlation dengan dibantu alat pengujian (software) SPSS versi 21 dengan syarat valid yang menjadi acuan dalam penelitian ini adalah bahwa $r$ hitung $>r$ tabel (0,146). Dalam arti hasil uji validitas harus lebih besar dari pada 0,146, sehingga item dapat dikatakan valid, dapat disimpulkan bahwa dari ketiga variabel yaitu transformational leadership, self-efficacy dan job performance memiliki skor nilai $\mathrm{r}$ hitung lebih besar dari pada $\mathrm{r}$ tabel ( $\mathrm{r}$ hitung $>\mathrm{r}$ tabel). Sehingga, hasil pengujian validitas terhadap items tiga variabel tersebut dapat dinyatakan valid karena seluruh instrument memenuhi syarat.

Pada penelitian ini uji reliabilitas dapat diketahui dengan melihat cronbache's alpha, apabila nilai cronbache's alpha lebih dari 0,60 maka instrument penelitian dapat dikatakan reliable dengan nilai Cronbach's Alpha untuk variable transformational leadership sebesar0,719, self-efficacy 0,714, job performance 0,697, sehingga semua variable dinyatakan reliabel.

\section{Menurut Ghozali}

mengungkapkan bahwa tujuan dari uji normalitas adalah untuk menguji apakah model regresi, variabel pengganggu atau residual memiliki distribusi normal. Normalitas ini dapat dideteksi dengan menggunakan uji statistik non-parametrik kolmogrov-smirnov K-S, apabila signifikansi

\begin{tabular}{|c|c|c|}
\hline & & $\begin{array}{c}\text { Understandized } \\
\text { Residual }\end{array}$ \\
\hline $\mathrm{N}$ & & 128 \\
\hline \multirow[t]{2}{*}{ Normal Parameters $^{2}$} & Mean & .0000000 \\
\hline & Std. Deviation & 1.69923535 \\
\hline \multirow[t]{3}{*}{ Most Extreme Diffrerences } & Absolute & .084 \\
\hline & Positive & .069 \\
\hline & Negative & -.084 \\
\hline Kolmogorov-Smirnov Z & & .953 \\
\hline Asymp. Sig. (2-failed) & & .323 \\
\hline
\end{tabular}
lebih besar dari $\alpha=0,05$, maka data tersebut berdistribusi normal. Hasil uji normalitas dapat dilihat pada Tabel 1 berikut:

Tabel 1. Uji Normalitas One-sample Kolmogorov-Smirnov Test

Berdasarkan hasil uji normalitas yang terdapat pada Tabel 1 di atas menunjukkan bahwa hasil residual telah berdistribusi normal. Hal ini dapat dilihat dari perolehan nilai signifikansi $(0,323)$ yang lebih besar dari 0,05 , disisi lain hal ini menunjukkan bahwa sebaran data tidak menunjukkan penyimpangan dari kurva normalitas. Sehingga, hasil ini dapat disimpulkan bahwa memenuhi asumsi normalitas. 


\section{Jurnal Ilmiah Manajemen dan Bisnis}

Uji ini bertujuan untuk menguji apakah dalam model regresi ditemukan adanya korelasi antar variabel bebas (independen). Model regresi yang baik seharusnya tidak terdapat korelasi diantara variabel independen. Untuk mendeteksi ada tidaknya multikolinieritas di dalam regresi ada beberapa cara, salah satunya adalah dengan dilihat dari variance inflation factor (VIF) dan nilai tolerance. Nilai yang umum digunakan untuk menunjukkan adanya multikolinieritas adalah nilai tolerance $<0,10$ atau sama dengan nilai VIF > 10 (Ghozali, 2009:95-98). Hasil uji multikolinieritas dapat dilihat pada Tabel 2 berikut:

\begin{tabular}{cccc}
\multicolumn{4}{c}{ Tabel 2. Uji Multikolinieritas } \\
\hline Variabel & Tolerance & VIF & $\begin{array}{c}\text { Hasil } \\
\text { Keputusan }\end{array}$ \\
\hline $\begin{array}{c}\text { Tranformational } \\
\text { Leadership }\left(\mathbf{X}_{\mathbf{1}}\right) \\
\text { Self-Efficacy } \\
\left(\mathbf{X}_{\mathbf{2}}\right)\end{array}$ & 0,998 & 1,002 & $\begin{array}{c}\text { Tidak terjadi } \\
\text { multikolinieritas } \\
\text { Tidak terjadi } \\
\text { multikolinieritas }\end{array}$ \\
\hline
\end{tabular}

Sumber : Data Diolah (2019)

Berdasarkan tabel 2, hasil pengujian multikolinieritas diperoleh nilai tolerance< 0,01 atau nilai VIF (Variance Inflation Factor) $>10$. Sehingga dapat dikatakan semua konsep pengukur variabel-variabel yang digunakan tidak mengandung masalah multikolinieritas. Maka model regresi yang ada layak untuk dipakai dalam memprediksi variabel dependen yaitu job performance.

Heteroskedastisitas dideteksi dengan menggunakan scatterplot yaitu dengan memplotkan standardized predictors dengan standardized residual model. Jika tidak ada pola yang jelas, serta titik-titik menyebar di atas dan di bawah angka 0 pada sumbu $Y$, maka tidak terjadi heteroskedastisitas (Ghozali, 2009). Berikut hasil scatterplot yang didapatkan dari output SPSS:

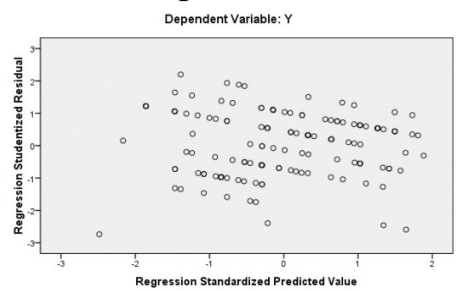

Gambar 2. Hasil Uji Heteroskedastisitas
Berdasarkan hasil uji heteroskedastistas pada Gambar 2 di atas terlihat bahwa scatterplot tidak membentuk suatu pola tertentu, serta titik menyebar di atas dan di bawah angka 0 pada sumbu Y. Maka dapat disimpulkan bahwa tidak terjadi heteroskedastisitas.

Ghozali (2009) menyatakan bahwa koefisien determinasi $\left(\mathrm{R}^{2}\right)$ pada intinya mengukur seberapa jauh kemampuan model dalam menerangkan variasi variabel dependen. Koefisien determinasi ini digunakan untuk mengetahui seberapa besar pengaruh variabelvariabel bebas terhadap variabel terikat. Berikut merupakan hasil analisis determinasi antara variabel transformational leadership $\left(\mathrm{X}_{1}\right), \quad$ self-efficacy $\left(\mathrm{X}_{2}\right)$ terhadap job performance (Y). Hasil uji koefisien determinasi dapat ditunjukkan pada Tabel 3 berikut ini:

Tabel 3. Hasil Analisis Determinasi

\begin{tabular}{cc}
\hline Model & Adjusted R Square \\
\hline 1 & .549
\end{tabular}

Dependent Variable: Kinerja Pegawai

Hasil analisis determinasi pada Tabel 3 menunjukkan bahwa persentase pengaruh variabel independen yaitu transformational leadership $\left(\mathrm{X}_{1}\right)$, self-efficacy $\left(\mathrm{X}_{2}\right)$ terhadap variabel dependen (Y) yaitu job performance sebesar $54,9 \%$. Sehingga dapat dikatakan bahwa variasi variabel independen yang digunakan dalam model mampu menjelaskan sebesar 54,9\%. Sedangkan sisanya sebesar $45,1 \%$ dipengaruhi atau dijelaskan oleh variabel lain.

Berdasarkan pada hasil perhitungan dari model regresi linier berganda, diperoleh hasil regresi yang dapat dilihat pada Tabel 4 .

\begin{tabular}{lccc}
\multicolumn{4}{c}{ Tabel 4. Hasil Uji t dan Uji F } \\
\hline \multicolumn{1}{c}{ Variabel } & $\begin{array}{c}\text { Koef. } \\
\text { Regresi }\end{array}$ & t hitung & Sig. \\
\hline $\begin{array}{l}\text { Transformational Leadership }\left(\mathrm{X}_{1}\right) \rightarrow \text { Job } \\
\text { Performance }(\mathrm{Y})\end{array}$ & 0,214 & 4,437 & 0,000 \\
Self-Efficacy $\left(\mathrm{X}_{2}\right) \rightarrow$ Job Performance $(\mathrm{Y})$ & 0,052 & 0,616 & 0,539 \\
Sig. F $=0,000$ & & & \\
F hitung $=10,180$ & & & \\
F tabel $=3,07$ & & & \\
\hline
\end{tabular}




\section{Jurnal Ilmiah Manajemen dan Bisnis}

Tabel 4, diketahui bahwa pengujian secara parsial variabel transformational leadership memperoleh nilai $\mathrm{t}$ hitung $>\mathrm{t}$ tabel $(4,437>1,979)$, dan perolehan nilai probabilitas pada kolom Sig adalah 0,000 atau probabilitas dibawah $0,05(0,000<0,05)$. Hal ini memberikan arti bahwa transformational leadership berpengaruh signifikan terhadap job performance. Nilai koefisien regresi positif $(0,214)$ menandakan bahwa transformational leadership berpengaruh positif terhadap job performance. Sehingga, dapat disimpulkan bahwa transformational leadership berpengaruh positif dan signifikan terhadap job performance. Sedangkan, variabel self-efficacy memperoleh nilai $\mathrm{t}$ hitung $<\mathrm{t}$ tabel $(0,616>1,979)$, dan perolehan nilai probabilitas pada kolom Sig adalah 0,539 atau probabilitas lebih besar dari pada 0,05 $(0,000<0,05)$. Hal ini memberikan arti bahwa self-efficacy berpengaruh tidak signifikan terhadap job performance. Nilai koefisien regresi positif $(0,052)$ menandakan bahwa self-efficacy berpengaruh positif terhadap job performance. Sehingga, dapat disimpulkan bahwa self-efficacy berpengaruh positif dan tidak signifikan terhadap job performance.

Pada tabel 4, menunjukkan hasil pengujian secara simultan yang menguji model apakahtransformational leadership dan self-efficacy berpengaruh terhadap job performance. Dapat dilihat dari nilai $\mathrm{F}$ hitung $(10,180)>$ nilai $F$ tabel $(3,07)$, dan apabila dilihat dari nilai signifikansi, diketahui nilai $\operatorname{sig}<0,05(0,000<0,05)$. Hal ini memberikan arti bahwa variabel transformational leadership dan self-efficacy secara simultan berpengaruh signifikan terhadap job performance.

\section{Pembahasan}

Pada pengujian hipotesis ditemukan bahwa a transformational leadership memiliki pengaruh positif dan signifikan terhadap job performance karyawan. Kepemimpinan transformasional ini diyakini sebagai suatu transformasi dimana atasan dalam hal ini pemimpin dan bawahan terlibat dalam proses saling memacu satu sama lain, dengan tujuan untuk mencapai tingkat yang lebih tinggi dalam moralitas dan motivasi (Brandt et al., 2016). Tidak dapat dipungkiri bahwa kepemimpinan ini merupakan salah satu kekuatan dan pendorong utama untuk meningkatkan kinerja (Zhu et al., 2005). Kepemimpinan transformasional disini lebih kepada pemimpin dalam menciptakan visi strategis, mengkomunikasikan visi tersebut, dan bertindak untuk melaksanakan secara konsisten, dan membangun komitmen terhadap visi tersebut (Avolio, 1999). Hal ini mencerminkan bahwa kepemimpinan transformasional sangat diperlukan untuk menunjang keberhasilan dalam menjalankan fungsi manajemen suatu organisasi, pada sisi yang lain juga dapat menghasilkan tingkat kohesi, komitmen, kepercayaan, motivasi, dan kinerja yang lebih tinggi dalam lingkungan organisasi (Zhu et al., 2005). Hasil temuan ini bukanlah temuan yang pertama dalam penelitian, namun temuan ini konsisten dengan beberapa hasil temuan terdahulu seperti Balthazard et al., (2009); Lievens et al., (1997); Eliyana et al., (2019); Howell \& Hallmerenda(1999); Avolio, (1999). Hasil penelitian ini melaporkan bahwa semakin tinggi pemimpin dalam menerapkan transformational leadership dapat berimplikasi pada kinerja karyawan yang lebih baik. Tingginya kinerja karyawan ini dapat berimplikasi pada peningkatan kinerja organisasi secara keseluruhan, begitu juga sebaliknya. Pada penelitian ini, terdapat beberapa hal yang perlu dilakukan oleh pemimpin untuk mendongkrak semangat bawahannya, seperti; memberikan inspirasi bagi bawahan untuk bertindak lebih, dan mengutamakan kepentingan organisasi dari pada kepentingan pribadi, pemimpin juga diharapkan mampu memberikan motivasi dan menjelaskan tujuan-tujuan organisasi dengan cara yang sederhana (simple) agar mudah untuk dicerna dan dipahami oleh bawahan. Disisi lain, pemimpin diharapkan mampu 


\section{Jurnal Ilmiah Manajemen dan Bisnis}

ISSN 1693-7619 (Print) I ISSN 2580-4170 (Online)

menunjukkan kepada karyawan tentang bagaimana menyelesaikan permasalahan dalam organisasi melalui cara-cara yang baru bukan dengan cara yang lama, dimana cara tersebut dapat diakui sebagai cara yang lebih efektif dan efisien dalam penyelesaian masalah yang ada dalam organisasi. Selain itu, pemimpin memberikan perhatian kepada karyawan secara invidivu dan mendorong bawahannya untuk terus berkembang dalam menjalani pekerjaan mereka, serta memberikan perhatian khusus pada kebutuhan setiap karyawan/bawahan dalam hal prestasi dan pengembangan karyawan. Sehingga, dari ini transformational leadership penting untuk terus dijaga dan diterapkan sebagai dasar untuk peningkatan terhadap kinerja karyawan pada perusahaan PT. Panca Mitra Multiperdana. Hal ini sesuai dengan yang disampaikan oleh Birasnav (2014) bahwa kepemimpinan transformasional merupakan kepemimpinan yang paling efektif dan sesuai dengan karyawan.

\section{Self-efficacy}

berpengaruh tidak signifikan terhadap job performance. Selfefficacy diartikan sebagai keyakinan seorang karyawan terhadap kemampuan yang dimilikinya dalam melaksanakan dan menyelesaikan tugas pekerjaan yang dihadapi, sehingga mampu mengatasi rintangan dan mencapai tujuan yang mereka harapkan. Namun, dalam penelitian ini menemukan hasil yang kontra dengan beberapa hasil studi terdahulu yang diajukan dalam penelitian ini. Dimana, self-efficacy berpengaruh positif dan tidak signifikan dalam meningkatkan kinerja karyawan. Hasil ini tidak mendukung hasil penelitian terdahulu seperti yang dikemukakan oleh Bandura (1997)yang memberikan simpulan bahwa seseorang yang memiliki selfefficacy yang tinggi lebih percaya bahwa mereka akan mampu mencapai kinerja terbaik pada pekerjaannya. Temuan ini juga tidak konsisten dengan hasil temuan peneliti terdahulu (Lunenburg, 2011; Carter et al., 2016; Clercq et al., 2018). Alasan self-efficacy memiliki pengaruh tidak signifikan terhadap kinerja karyawan, dikarenakan karyawan merasa bahwa pekerjaan mereka secara sistematis telah diatur oleh organisasi, sehingga tidak membutuhkan aktualisasi diri yang lebih terkait dengan kepercayaan diri karyawan dalam bekerja. Disisi yang lain, karyawan kurang yakin dalam menganalisis masalah dan menemukan solusi atas masalah tersebut, dan juga karyawan kurang percaya diri dalam membantu menetapkan target/sasaran dalam area kerja mereka. Padahal menurut Sujan et al. (1994) pada organisasi yang berorientasi pada kinerja, seharusnya self-efficacy yang tinggi dapat memotivasi karyawan untuk bekerja lebih keras dari pada rekan kerja mereka yang memiliki self-efficacy yang rendah. Selain itu, Organisasi sebagai tempat berlangsungnya aktivitas kerja karyawan seharus mendukung self-efficacy karyawan, karena pada hasil penelitian ini memiliki pengaruh yang positif terhadap peningkatan kinerja, namun pengaruhnya tidak cukup signifikan. Temuan penelitian ini mendukung hasil temuan penelitian yang dilakukan oleh Sihombing et al. (2018) dan Kaseger (2013) yang menyatakan bahwa self-efficacy berpengaruh tidak signifikan terhadap job performance karyawan.

Pada hasil penelitian ini ditemukan bahwa variabel independen (transformational leadership dan self-efficacy)dalam penelitian ini berpengaruh positif dan signifikan terhadap job performance secara simultan. Hasil ini sesuai dengan hasil penelitian yang dilakukan oleh Kilapong (2013)yang menyatakan bahwa transformational leadership dapat memotivasi karyawan karena motivasi merupakan salah satu faktor yang mendorong timbulnya kepuasan kerja karyawan, yang pada gilirannya akan meningkatkan kinerja karyawan (Engko, 2008). Selain itu, jika seorang karyawan memiliki self-efficacy yang tinggi mereka lebih cenderung berhasil dalam tugasnya dan pada akhirnya dapat meningkatkan kinerjanya (Kilapong, 2013 dan Engko, 2008). Disisi lain, Fadzilah (2006) 


\section{Jurnal Ilmiah Manajemen dan Bisnis}

menyampaikan bahwa dengan adanya selfefficacy yang baik dapat menjadi pendorong psikologis karyawan dalam memberikan hasil kerja yang maksimal.

\section{SIMPULAN}

Berdasarkan hasil penelitian dan analisis di atas menunjukkan bahwa transformational leadership berpengaruh positif dan signifikan terhadap job performance karyawan.Disisi yang lain, self-efficacy berpengaruh positif dan tidak signifikan terhadap job performance karyawan. Secara simultan, kedua variabel konstruk kinerja yaitu transformational leadership dan self-efficacy berpengaruh positif dan signifikan terhadap job performance. Penelitian yang selanjutnya diharapkan dapat menyempurnakan hasil penelitian ini, dengan menambahkan variabel yang dapat menjadi anticident untuk pengaruh yang lebih besar pada job performance. Penelitian mendatang juga diharapkan dapat memperluas scope penelitianyang memiliki karakteristik yang sama dimana dalam penelitian ini hanya dilakukan pada satu objek organisasi, sehingga hasil dan dampak penelitian yang diberikan cukup luas. Selain itu, penelitian mendatang juga disarankan untuk menggunakan metode SEM PLS sebagai metode analisis yang digunakan dalam peneltiannya untuk mengetahui hasil yang lebih konfrehensif.

\section{REFERENSI}

Abbas, M., Raja, U., Darr, W., \& Bouckenooghe, D. (2014). Combined Effects of Perceived Politics and Psychological Capital on Job Satisfaction , Turnover Intentions , and Performance. Journal of Management, 40(7), 18131830.

https://doi.org/10.1177/01492063124552 43

Avolio, B. J. (1999). Full leadership development: Building the vital forces in organizations. Thousand Oaks: CA7 Sage.
Balthazard, P. A., Waldman, D. A., \& Warren, J. E. (2009). Predictors of the emergence of transformational leadership in virtual decision teams. The Leadership Quarterly, 20(5), 651-663. https://doi.org/10.1016/j.leaqua.2009.06. 008

Bandura, A. (1997). Self-Efficacy: The exercise of control. New York: W.H. Freeman.

Baron, R. A., \& Byrne, D. (2004). Psikologi Sosial. Jakarta: Erlangga.

Bass, B. M., Avolio, B. J., Jung, D. I., \& Berson, Y. (2003). Predicting Unit Performance by Assessing Transformational and Transactional Leadership. Journal of Applied Psychology, 88(2), 207-218. https://doi.org/10.1037/00219010.88.2.207

Bernardin, \& Russel. (1993). Human Resource Management (Internatio). New Jersey: Prentice Hall.

Birasnav, M. (2014). Relationship between transformational leadership behaviors and manufacturing strategy. International Journal of Organizational Analysis, 22(2), 205-223. https://doi.org/10.1108/IJOA-10-20110520

Brandt, T., Laitinen, E. K., \& Laitinen, T. (2016). The effect of transformational leadership on the profitability of Finnish firms. International Journal of Organizational Analysis, 24(1), 1-46.

Braun, S., Peus, C., Weisweiler, S., \& Frey, D. (2013). Transformational leadership , job satisfaction, and team performance: A multilevel mediation model of trust is. The Leadership Quarterly, 24(1), 270 283.

https://doi.org/10.1016/j.leaqua.2012.11. 006

Buil, I., Martínez, E., \& Matute, J. (2019). Transformational leadership and employee performance: The role of identi fi cation, engagement and 


\section{Jurnal Ilmiah Manajemen dan Bisnis}

proactive personality. International Journal of Hospitality Management, 77, 64-75.

https://doi.org/10.1016/j.ijhm.2018.06.01 4

Carter, W. R., Nesbit, P. L., Badham, R. J., Parker, S. K., \& Sung, L.-K. (2016). The effects of employee engagement and selfefficacy on job performance: a longitudinal field study. The International Journal of Human Resource Management, 1-20. https://doi.org/10.1080/09585192.2016.1 244096

Clercq, D. De, Haq, I. U., \& Azeem, M. U. (2018). Self-efficacy to spur job performance Roles of job-related anxiety and perceived workplace incivility. Management Decision, 56(4), 891-907. https://doi.org/10.1108/MD-03-20170187

Eliyana, A., Ma'arif, S., \& Muzakki. (2019). transformational leadership towards employee performance. European Research on Management and Business Economics, $1-7$. https://doi.org/10.1016/j.iedeen.2019.05. 001

Engko, C. (2008). Pengaruh Kepuasan Kerja Terhadap Kinerja Individual Dengan Self Esteem dan Self Efficacy Sebagai Variabel Intervening. Jurnal Bisnis Dan Akuntansi, 10(1), 1-12.

Fadzilah, A. (2006). Analisis Pengaruh Pemberdayaan Karyawan Dan Self of Efficacy Terhadap Kinerja Karyawan Bagian Penjualan (Studi Kasus Pada PT. Sinar Sosro Wilayah Pemasaran Semarang). Jurnal Studi Manajemen \& Organisasi, 3(1), 12-27.

Gabcanova, I. (2011). The Employees - The Most Important Asset In The Organizations. Human Resources Management \& Ergonomics, $V, 1-12$.

Ghozali, I. (2009). Aplikasi Analisi Multivariance Dengan Program SPSS (B. P. U. Diponegoro, ed.). Semarang.
Givens, R. J. (2008). Transformational Leadership : The Impact on Organizational and Personal Outcomes. Emerging Leadership Journeys, 1(1), 424.

Howell, J. M., \& Hall-merenda, K. E. (1999). The Ties That Bind: The Impact of Leader-Member Exchange Transformational and Transactional Leadership , and Distance on Predicting Follower Performance. Journal of Applied Psychology, 84(5), 680-694.

Kaseger, R. G. (2013). Pengembangan Karir Dan Self-Efficacy Terhadap Kinerja Karyawan Pada PT. Matahari Department Store Manado Town Square. Jurnal EMBA, 1(4), 906-916.

Kilapong, S. N. (2013). Kepemimpinan Transformasional, Self Efficacy, Self Esteem Pengaruhnya Terhadap Kepuasan Kerja Karyawan PT. Tropica Cocoprima Manado. Jurnal EMBA, 1(4), 141-150.

Koesmono, H. T. (2005). Pengaruh Budaya Organisasi Terhadap Motivasi Dan Kepuasan Kerja Serta Kinerja Karyawan Pada Sub Sektor Industri Pengolahan Kayu Skala Menengah Di Jawa Timur. Jurnal Manajemen \& Kewirausahaan, 7(2), 171-188.

Lievens, F., Geit, P. Van, \& Coetsier, P. (1997). Identification of Transformational Leadership Qualities: An Examination of Potential Biases. European Journal of Work And Organizational Psychology, 6(4), 415430.

https://doi.org/10.1080/13594329739901 5

Lunenburg, F. C. (2011). Self-Efficacy in the Workplace: Implications for Motivation and Performance. International Journal Of Management, Business, And Administration, 14(1), 1-6.

Luthans, F., Avolio, B. J., Avey, J. B., \& Norman, S. M. (2007). Positive Psychological Capital : Measurement and Relationship with Performance and 


\section{Jurnal Ilmiah Manajemen dan Bisnis}

Published, Volume 20 Nomor 2, Oktober 2019, 82 - 91

ISSN 1693-7619 (Print) I ISSN 2580-4170 (Online) http://jurnal.umsu.ac.id/index.php/mbisnis

Satisfaction. Personnel Psychology, 60, 541-572.

Parker, S. K. (1998). Enhancing Role Breadth

Self-Efficacy: The Roles of Job Enrichment and Other Organizational Interventions. Journal of Applied Psychology, 83(6), 835-852.

Pervin, L. ., \& John, O. . (2001). Personality; Theory and Reasearch (8th ed.). New York: John Wiley \& Sons, Inc.

Piccolo, R. F., \&Colquitt, J. A. (2006). Transformational Leadership And Job Behaviors: The Mediating Role Of Core Job Characteristics. Academy OfManagement Journal, 49(2), 327-340.

Robbins, S. P., Judge, T. A., \& Sanghi, S. (2009). Organizational Behavior (13th ed). New Delhi: Doring Kindersley Pvt. Ltd.

Sihombing, E. P., Sendow, G. M., \& Uhing, Y. (2018). The Influence Of Individual Characteristics, Job Characteristics, Self Efficacy And Employee Performance at PT. PLN (Persero) Rayon Manado Selatan. Jurnal EMBA, 6(4), 2858-2867.

Sujan, H., Weitz, B. A., \& Kumar, N. (1994). Learning Orientation, Working Smart, and Effective Selling. Journal of Marketing, 58(3), 39-52.

Thoha, M. (2006). Kepemimpinan dalam Manajemen. Jakarta: PT. Raja Grafindo Perkasa.

Williams, L. J., \& Anderson, S. E. (1991). Job Satisfaction and Organizational Commitment as Predictors of Organizational Citizebship and In-Role Behaviors. Journal of Management, 17(3), 601-617.

Zhu, W., Chew, I. K. H., \& Spangler, W. D. (2005). CEO transformational leadership and organizational outcomes: The mediating role of human - capitalenhancing human resource management. The Leadership Quarterly, 16, 39-52. https://doi.org/10.1016/j.leaqua.2004.06. 001. 